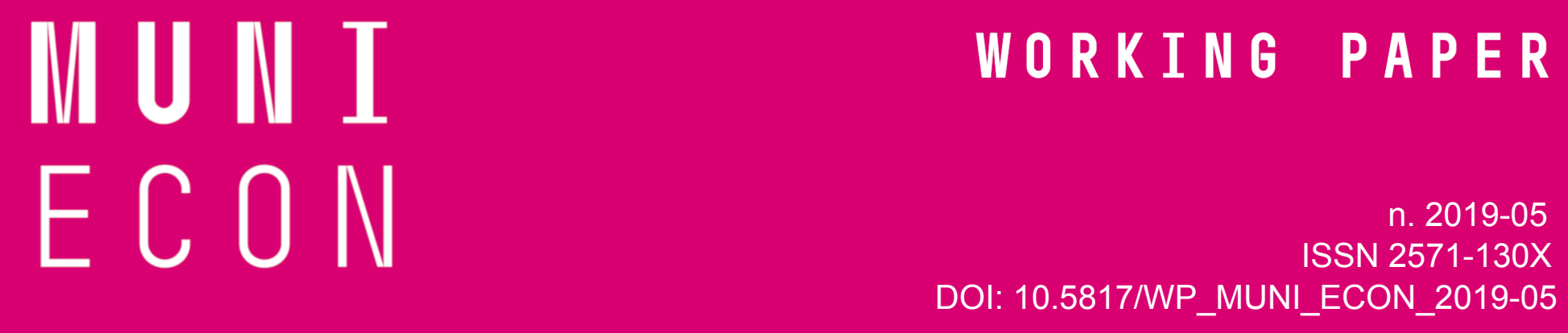

Published in: Research in Economics, 2019, Article

\title{
Made for the job or by the job? A lab-in-the-field experiment with firefighters
}




\section{Made for the job or by the job? A lab-in-the-field experiment with firefighters}

\section{Abstract}

A large body of evidence supports a negative association between risk aversion of workers and the level of risk they face in their occupations. This relationship could be explained by the self-selection of workers into jobs according to their risk preferences or by the effect on risk attitudes of occupations in which people face or witness dangerous situations. We use incentivized experiments to measure risk preferences among three different groups: experienced firefighters, novice firefighters, and students. We find that experienced firefighters are less riskaverse than novice firefighters, and these in turn are less risk-averse than students. The effects remain significant even after controlling for other relevant differences between these groups. Our findings suggest that the observed relationship between risk aversion and high-risk occupations is not only a result of self-selection but also of people's preferences being shaped by their work lives.

Masaryk University

Faculty of Economics and Administration

Authors:

Ondřej Krčál (ORCID: 0000-0002-8575-1203) / Masaryk University

Rostislav Staněk (ORCID: 0000-0002-6310-4777) / Masaryk University

Martin Slanicay / Masaryk University

Contact: ondrej.krcal@econ.muni.cz

Creation date: 2019-04

Revision date: 2023-01

Keywords: risk preferences, high-risk occupations, self-selection, lab-in-the-field experiment JEL classification:

Citation:

Krčál, O., Staněk, R., Slanicay, M. (2019). Made for the job or by the job? A lab-in-the-field experiment with firefighters. MUNI ECON Working Paper n. 2019-05. Brno: Masaryk University. https://doi.org/10.5817/WP_MUNI_ECON_2019-05 


\title{
Made for the job or by the job? A lab-in-the-field experiment with firefighters
}

\author{
Ondřej Krčál ${ }^{\mathrm{a}, *}$, Rostislav Staněk ${ }^{\mathrm{a}}$, Martin Slanicay ${ }^{\mathrm{a}}$ \\ ${ }^{a}$ Faculty of Economics and Administration, Masaryk University, Lipová 41a, 60200 Brno, Czech Republic
}

\begin{abstract}
A large body of evidence supports a negative association between risk aversion of workers and the level of risk they face in their occupations. This relationship could be explained by the self-selection of workers into jobs according to their risk preferences or by the effect on risk attitudes of occupations in which people face or witness dangerous situations. We use incentivized experiments to measure risk preferences among three different groups: experienced firefighters, novice firefighters, and students. We find that experienced firefighters are less risk-averse than novice firefighters, and these in turn are less risk-averse than students. The effects remain significant even after controlling for other relevant differences between these groups. Our findings suggest that the observed relationship between risk aversion and high-risk occupations is not only a result of self-selection but also of people's preferences being shaped by their work lives.
\end{abstract}

Keywords: risk preferences, high-risk occupations, self-selection, lab-in-the-field experiment

\section{Introduction}

People base their career choices on their skills and training, and also on their preferences. Risk preferences are important in this respect as different occupations are associated with varying levels of risk. A large body of evidence indicates a negative association between the risk aversion of workers and the level of risk they face in their

5 work lives. Using standard experimental lottery measures of risk aversion on US data, Barsky et al. (1997), Ahn (2010) and Brown et al. (2006) find that self-employed people are more risk-seeking than employees. Cramer et al. (2002), Hartog et al. (2002), Masclet et al. (2009), Brown et al. (2011), and Skriabikova et al. (2014) report similar findings for European labor markets. Using investment data for 400,000 individuals in Norway, Hvide and Panos (2014) find that common stock investors are around $50 \%$ more likely to subsequently start up a firm. Bonin et al. (2007) use data from representative sample of the German population to show that self-assessment of risk attitudes is correlated with cross-sectional variations in earnings. Di Mauro and Musumeci (2011) find similar results for a sample of 258 Italians aged between 25 and 40 . If risk preferences are set and do not change during a worker's life, these findings can be explained by the self-selection of workers into jobs according to their risk attitudes.

Yet a growing literature documents that risk preferences may change if people are exposed to one-off traumatic experiences, such as natural catastrophes or wars (Eckel et al., 2009; Malmendier et al., 2011; Voors et al., 2012;

\footnotetext{
*Corresponding author. Tel.: +420 549496332

Email addresses: krcalo@mail.muni.cz (Ondřej Krčál), rostanek@mail.muni.cz (Rostislav Staněk), slanicay@mail.muni.cz (Martin Slanicay)
} 
Bucciol and Zarri, 2013; Kim and Lee, 2014; Cameron and Shah, 2015; Hanaoka et al., 2016; Cassar et al., 2017; Shupp et al., 2017), if they live under specific conditions for a long period of time, for example if they live in disaster areas despite not having been directly affected by any disaster (Bchir and Willinger, 2013; Cassar et al., 2017; Shupp et al., 2017), if they have lower wealth or income (Guiso and Paiella, 2008; Tanaka et al., 2010), or if they have 20 lived through an era of low stock market returns (Malmendier and Nagel, 2011; Ampudia and Ehrmann, 2017; Malmendier et al., 2011). The direction of the effect is not clear. Some studies indicate that exposure increases risk aversion while other studies find that it reduces risk aversion. In any case, the available evidence raises the possibility that risk preferences could be changed by work involving risk or danger.

If the exposure to risk on the job affects risk aversion, the explanation of the relationship between risk preferences 25 and riskiness of work would need to be revised, and the revision would depend on the direction of the effect. If exposure to risk at work reduces risk aversion, the role of self-selection in the observed correlation between risk attitudes and on-the-job risks might be lower than previously observed or even nonexistent. If, on the other hand, the exposure to work-related danger increases risk aversion, the role attributed to self-selection might be even larger than what is observed in the data.

This is relevant for at least two reasons. The first reason is related to the role of self-selection in labor markets. One outcome of self-selection into jobs is increased efficiency (Bonin et al., 2007). ${ }^{1}$ If people are free to choose the occupation that best fits their preferences and their preferences differ substantially, the result is a more efficient allocation in the labor market; in contrast, if people are more similar at the beginning and their differences are deepened during their time at work, self-selection is less beneficial than might have been concluded from the available evidence. The second reason is that it is important to know whether jobs involving danger impact preferences. If exposure to dangerous situations makes soldiers or firefighters too risk-seeking, these workers might make choices that could put other people in danger, especially if they are in charge. ${ }^{2}$ In addition to that, changes in preferences might spill over into the private lives of these workers. People in high-risk jobs might require more intensive psychological care to prevent any adverse effects on their lives outside of work.

In this paper, we use a lab-in-the field experiment with firefighters to assess the role of self-selection and long-term job exposure to risk in risk preferences. Firefighting is a suitable occupation for this analysis because firefighters face a non-negligible chance of being injured during their career. They are also more likely to witness traffic accidents or fire-related injuries and deaths on a regular basis (for more details see Section 2). Moreover, since Czech firefighters have a low turnover rate, they are ideal for measuring the effect of long-term employment on preferences. Apart 45 from the high status that Czech firefighters enjoy, the main reason for the low turnover is that they are entitled to special pension conditions if they serve for at least 15 years.

\footnotetext{
${ }^{1}$ There are some conditions for the allocative efficiency of this self-selection, such as that workers have complete information about the risks of a job and are free to choose among different employers.

${ }^{2}$ On the other hand, as the very nature of these risky jobs actually requires workers to take risks, it may well be the case that soldiers and firefighters are still too risk-averse from a normative perspective, e.g. because they put their own health and safety well over and above that of others. It may also counterbalance the opposite effect of ageing, i.e. older people getting more risk-averse.
} 
To measure risk aversion, we use the bomb risk elicitation task (BRET) by Crosetto and Filippin (2013). We selected this task for its intuitiveness, which makes it especially suitable for field experiments. To test the effects of long-term job exposure, we compare the risk aversion of experienced firefighters to that of novice firefighters who are in their initial training at the corps. The role of self-selection was estimated by comparing novice firefighters and students. To ensure that our results are sound, we control for several factors that are known to be correlated with risk aversion. We find evidence of the job-exposure effect: experienced firefighters are less risk-averse than firefighters in their initial training. We also find that novice firefighters are less risk-averse than their student peers.

The rest of this paper proceeds as follows. Section 2 provides information about firefighters in the Czech Republic. Section 3 describes the experimental design and procedure in detail. Section 4 presents our data and results. Section 5 provides a discussion of our findings.

\section{Firefighters in the Czech Republic}

In 2017, there were around 9,500 firefighters in the Czech Republic, 6,500 of whom were regularly sent on interventions. During these interventions, firefighters face non-negligible chances of being injured. There were 236

60 year. Firefighters in service are also exposed to a high frequency of critical events. There were 125,974 incidents with firefighter intervention in 2017 , of which about $13 \%$ were fires, about $18 \%$ were traffic accidents, about $6 \%$ were hazardous materials leakages and about $56 \%$ were technical accidents; the rest were false alarms. Firefighters thus potentially witness serious injuries or deaths of other people at one third of interventions. In terms of fires, there were 92 fatal injuries and 1,392 non-fatal injuries in 2017. ${ }^{3}$ This means that a firefighter may deal with a seriously injured person several times per month and may witness or be exposed to the death of another person a few times per year. Firefighter are therefore exposed to two types of potentially traumatic experiences: i) They are exposed to dangerous situations which may lead to (their own) serious injury or death, and ii) they witness serious injuries and deaths of other people.

Despite all this, Czech firefighters have a low turnover rate. In the cohort of intervention firefighters with less than 15 years in service, the yearly fraction of firefighters leaving the corps is $0.8 \%$. This means that, on average, only $11 \%$ of a one-year cohort leave during the first 15 years in service. The turnover rate is very low even after 15 years in service, which is when firefighters are entitled to special pension conditions. In the cohort with 15-20 years in service, the exit rate is $1.6 \%$, so the percentage of a one-year cohort of firefighters leaving withing the long-term employment on preferences.

\footnotetext{
${ }^{3}$ Statistical Yearbook 2017 of the Fire Rescue Service of the Czech Republic, http://www.hzscr.cz/hasicien/article/ statistical-yearbooks.aspx [accessed on 13/3/2019]

${ }^{4}$ The turnover rates are calculated from data provided by the Fire Rescue Service (FRS) of the Czech Republic.
} 


\section{Experimental design and procedures}

The pen-and-paper experiment was conducted twice. The experiment with firefighters took place in January 2017 and February 2019. The data from 91 students were collected in February 2017 and February 2019. The students registration for the experiment was done through hroot (Bock et al., 2012). The firefighters were participants in a training program at a training center in Brno (Czech Republic). Of 179 firefighters, 101 were novices participating in their initial training course. The new firefighters undergo a thorough selection process including a test of physical fitness and a psychological test. If the applicant passes these tests, he is enrolled into the trainee program. It usually takes some time before the new recruit starts the trainee program but most firefighters start the program within

85 the first six months of employment. Before the program is completed the exposure of the firefighter to dangerous situations is limited. The remaining 78 firefighters were more experienced. They had already passed their initial training and had, on average, 9.8 years in the fire rescue service. All firefighters are obliged to participate in regular training sessions, so there is no selection of experienced firefighters into the training program. There was also limited selection of firefighters into the experiment. Out of all firefighters (including instructors) involved in the program

90 at the training center on that day, less than 10 percent did not participate in our experiment, and the participation rate was similar among the experienced and novice firefighters.

Both firefighters and students completed the Bomb Risk Elicitation Task (BRET) developed by Crosetto and Filippin (2013). In this task, participants are shown a 10 x 10 grid with 100 cells in total. Each cell represents a box: 99 of these boxes are empty and one contains a bomb. The subjects know that each box has the same probability of containing the bomb, but they have no information regarding where the bomb is placed. The task is to choose how many boxes to open. Boxes from one to the stated number are then opened. If the box containing the bomb is one of the opened boxes, the bomb explodes and the participant earns CZK 0 from the BRET. If the box containing the bomb is not opened, the payoff equals CZK 3 times the number of opened boxes ${ }^{5}$.

\section{Results}

Our sample consists of 91 students and 179 firefighters. All subjects are males. For both groups, we have data on their ages and their choices in the BRET (bomb). Table 1 shows descriptive statistics of these two variables. The possible values in bomb range from 0 to 100. Risk-neutral preferences correspond the value of 50, higher values correspond to more risk-seeking preferences.

Additionally, we collected data about budget constraints in the student sample. We asked them the following question: How much money a week do you have for fun or hobbies after covering your necessary expenses (accommodation, food, clothes, textbooks, transport, etc.). For firefighters, we collected data about their rank, the number of years they had been firefighters (years in the corps), whether or not they had a university degree (university), and the number of children they had if any (children).

\footnotetext{
${ }^{5}$ The datasets generated during the current study and the experimental instructions are available from the corresponding author on request.
} 
Table 1

Descriptive statistics for age and choice in the BRET (bomb)

\begin{tabular}{|c|c|c|c|c|c|c|c|c|c|}
\hline & \multirow[t]{2}{*}{ Obs. } & \multicolumn{4}{|c|}{ Bomb } & \multicolumn{4}{|c|}{ Age } \\
\hline & & mean & s.d. & $\min$ & $\max$ & mean & s.d. & $\min$ & $\max$ \\
\hline Students & 91 & 41.4 & 10.87 & 20 & 75 & 22.7 & 2.0 & 19 & 29 \\
\hline Novice & 101 & 49.9 & 17.01 & 4 & 90 & 26.8 & 5 & 20 & 43 \\
\hline Experienced & 78 & 55.6 & 19.2 & 9 & 99 & 33.3 & 7.2 & 21 & 59 \\
\hline Total & 270 & 48.7 & 16.9 & 4 & 99 & 27.3 & 6.6 & 19 & 59 \\
\hline
\end{tabular}

Table 2 presents regression results for all students and firefighters. The dependent variable is the BRET choice. The higher the value, the more risk-seeking the person. We control for age in all the regressions except regression (1). These controls are crucial as these variables are known to be related to risk attitudes and the sex and age structures are different among students, novices, and experienced firefighters. Consistently with the literature, we find that risk aversion increases with age (Dohmen et al., 2011; Palsson, 1996; Gurdal et al., 2017).

\section{Table 2}

The OLS regression on data from all students and firefighters

\begin{tabular}{|c|c|c|c|c|c|}
\hline & \multicolumn{5}{|c|}{ Dependent variable: Bomb } \\
\hline & $(1)$ & $(2)$ & (3) & $(4)$ & $(5)$ \\
\hline Constant & $\begin{array}{c}49.871^{* * *} \\
(1.587)\end{array}$ & $\begin{array}{c}65.019^{* * *} \\
\quad(5.341)\end{array}$ & $\begin{array}{c}50.913 \\
(49.839)\end{array}$ & $\begin{array}{c}61.848^{* * *} \\
(6.499)\end{array}$ & $\begin{array}{c}64.563^{* * *} \\
(6.825)\end{array}$ \\
\hline Experienced & $\begin{array}{c}5.936^{* *} \\
(2.405)\end{array}$ & $\begin{array}{c}9.592^{* * *} \\
(2.671)\end{array}$ & $\begin{array}{c}9.235^{* * * *} \\
(2.695)\end{array}$ & $\begin{array}{c}9.651^{* * * *} \\
(2.674)\end{array}$ & $\begin{array}{c}9.303^{* * *} \\
(2.684)\end{array}$ \\
\hline Student & $\begin{array}{c}-8.509^{* * *} \\
(2.306)\end{array}$ & $\begin{array}{c}-10.869^{* * *} \\
(2.408)\end{array}$ & $\begin{array}{c}-9.994^{* * *} \\
(2.559)\end{array}$ & $\begin{array}{c}-8.239^{* *} \\
(3.900)\end{array}$ & $\begin{array}{c}-8.368^{* *} \\
(3.897)\end{array}$ \\
\hline Age & & $\begin{array}{c}-0.565^{* * *} \\
(0.191)\end{array}$ & $\begin{array}{c}0.221 \\
(4.504)\end{array}$ & $\begin{array}{c}-0.574^{* * *} \\
(0.191)\end{array}$ & $\begin{array}{c}-0.690^{* * *} \\
(0.211)\end{array}$ \\
\hline $\mathrm{Age}^{2}$ & & & $\begin{array}{l}-0.007 \\
(0.131)\end{array}$ & & \\
\hline $\mathrm{Age}^{3}$ & & & $\begin{array}{c}-0.0001 \\
(0.001)\end{array}$ & & \\
\hline Money & & & & $\begin{array}{c}3.419 \\
(3.989)\end{array}$ & $\begin{array}{c}3.556 \\
(3.986)\end{array}$ \\
\hline Children & & & & & $\begin{array}{c}4.988 \\
(3.874)\end{array}$ \\
\hline Observations & 270 & 270 & 270 & 270 & 270 \\
\hline $\mathrm{R}^{2}$ & 0.117 & 0.145 & 0.149 & 0.147 & 0.153 \\
\hline Adjusted $\mathrm{R}^{2}$ & 0.110 & 0.135 & 0.133 & 0.134 & 0.137 \\
\hline
\end{tabular}

The variable experienced shows that the firefighters with two or more years in the fire rescue service are more 
risk-seeking than novices. This result is robust for all specifications. In comparison to regression (2), regression (3) controls for a possible non-linear effect of age on risk preferences. The estimated effect of age is still close to linear and the effect of experience remains positive and highly significant. These results remain the same in regression (4), where the variable money is added. This is a dummy variable, where 1 includes all students with disposable income higher than CZK 1,000 or more per week and all firefighters. We add all firefighters to the least constrained group of students, because they earn a standard salary. Even for the novice firefighters with a net basic income of approx. CZK 16,000 (this income does not include bonuses or additional payments for night shifts) and the income after paying for necessities is clearly more than CZK 1,000 per week. In regression (5), we control for number of children because firefighters who have children can feel poorer compared to similar firefighters without children. The results are similar to the results of regression (4).

The variable student measures the difference between students and novice firefighters. The variable is negative and statistically significant in all regressions, so students are more risk-averse than their peers in the fire rescue service.

We provide two additional robustness checks. First, we run the analysis using only data from firefighters. This allows us to add additional control variables that are relevant only for firefighters, such as the university degree, years in the corps and rank. This way, we also control for potential differences in wealth, because the wages of the firefighters are determined by their rank, education, and years in the corps. As shown in Table 3, the effect of experience remains as significant as in the previous regressions. Second, we show that our results are robust to a change in the measure of experience. Instead of a binary variable, the regressions in Table 4 use years in the corps as a proxy for experience.

\section{Discussion}

There is empirical evidence of a negative relationship between risk aversion of workers and the level of risk they face in their occupations. This paper investigates two channels which might be responsible for this correlation. First, people might self-select into occupations according to their risk preferences. Second, exposure to risk might impact workers' attitudes toward risk. We find evidence for both channels. The novice firefighters are more risk-seeking than university students, and the experienced firefighters exhibit more risk-seeking preferences than the novices. The observed correlation between risk aversion and employment in a high-risk occupation is at least partly due to the impact work experience has on preferences.

Our findings are in line with the literature documenting the effect of background risk on risk preferences. By background risk, we mean continuous exposure to a risky environment with no or little direct harm - in this case - on the examined firefighters. In this sense, our paper is similar to Bchir and Willinger (2013), who examine individuals exposed to the background risk associated with lahars and find that poor individuals living in exposed areas are significantly more risk-seeking than those living in unexposed areas. This finding is also in line with the results of Malmendier et al. (2011), who find that managers with military experience pursue more risky policies. We believe that military and firefighting experience are comparable in their effects on risk preferences. Our paper is also closely 
Table 3

The OLS regression on data from firefighters

\begin{tabular}{|c|c|c|c|c|}
\hline & \multicolumn{4}{|c|}{ Dependent variable: Bomb } \\
\hline & (1) & $(2)$ & (3) & (4) \\
\hline Constant & $\begin{array}{c}65.925^{* * *} \\
(6.163)\end{array}$ & $\begin{array}{c}62.469 \\
(70.412)\end{array}$ & $\begin{array}{c}69.270^{* * *} \\
(7.927)\end{array}$ & $\begin{array}{c}49.525^{* * *} \\
(13.324)\end{array}$ \\
\hline Experienced & $\begin{array}{c}9.810^{* * *} \\
(3.022)\end{array}$ & $\begin{array}{c}9.404^{* * *} \\
(3.079)\end{array}$ & $\begin{array}{l}9.363^{* *} \\
(3.958)\end{array}$ & $\begin{array}{c}18.716^{* * *} \\
(5.096)\end{array}$ \\
\hline Age & $\begin{array}{c}-0.599^{* * *} \\
(0.220)\end{array}$ & $\begin{array}{l}-0.743 \\
(6.228)\end{array}$ & $\begin{array}{c}-0.730^{* *} \\
(0.302)\end{array}$ & $\begin{array}{c}-0.559^{*} \\
(0.314)\end{array}$ \\
\hline $\mathrm{Age}^{2}$ & & $\begin{array}{c}0.019 \\
(0.176)\end{array}$ & & \\
\hline Age $^{3}$ & & $\begin{array}{c}-0.0003 \\
(0.002)\end{array}$ & & \\
\hline University degree & & & $\begin{array}{l}-0.651 \\
(3.360)\end{array}$ & $\begin{array}{c}0.085 \\
(4.014)\end{array}$ \\
\hline Children & & & $\begin{array}{c}5.175 \\
(4.437)\end{array}$ & $\begin{array}{c}3.337 \\
(4.578)\end{array}$ \\
\hline Years in the corps & & & $\begin{array}{c}0.027 \\
(0.407)\end{array}$ & $\begin{array}{l}-0.179 \\
(0.430)\end{array}$ \\
\hline Rank fixed effects & No & No & No & Yes \\
\hline Observations & 179 & 179 & 179 & 179 \\
\hline $\mathrm{R}^{2}$ & 0.066 & 0.070 & 0.074 & 0.130 \\
\hline Adjusted $\mathrm{R}^{2}$ & 0.055 & 0.048 & 0.047 & 0.067 \\
\hline
\end{tabular}


Table 4

OLS regression on data from firefighters

\begin{tabular}{|c|c|c|c|c|}
\hline & \multicolumn{4}{|c|}{ Dependent variable: Bomb } \\
\hline & (1) & $(2)$ & $(3)$ & $(4)$ \\
\hline \multirow[t]{2}{*}{ Constant } & $69.733^{* * *}$ & 20.382 & $72.776^{* * *}$ & $63.882^{* * *}$ \\
\hline & $(7.453)$ & $(71.084)$ & $(7.889)$ & $(13.205)$ \\
\hline \multirow[t]{2}{*}{ Years in the corps } & $0.681^{* *}$ & $0.774^{* *}$ & $0.639^{* *}$ & $0.684^{*}$ \\
\hline & $(0.316)$ & $(0.322)$ & $(0.319)$ & $(0.373)$ \\
\hline \multirow[t]{2}{*}{ Age } & $-0.692^{* *}$ & 2.918 & $-0.819^{* * *}$ & $-0.764^{* *}$ \\
\hline & $(0.281)$ & $(6.317)$ & $(0.304)$ & $(0.320)$ \\
\hline \multirow[t]{2}{*}{$\mathrm{Age}^{2}$} & & -0.077 & & \\
\hline & & $(0.180)$ & & \\
\hline \multirow[t]{2}{*}{$\mathrm{Age}^{3}$} & & 0.0004 & & \\
\hline & & $(0.002)$ & & \\
\hline \multirow[t]{2}{*}{ University degree } & & & 0.378 & 1.022 \\
\hline & & & $(3.375)$ & $(4.153)$ \\
\hline \multirow[t]{2}{*}{ Children } & & & 5.568 & 4.217 \\
\hline & & & $(4.492)$ & $(4.740)$ \\
\hline Rank fixed effects & No & No & No & Yes \\
\hline Observations & 179 & 179 & 179 & 179 \\
\hline $\mathrm{R}^{2}$ & 0.035 & 0.051 & 0.044 & 0.059 \\
\hline Adjusted $\mathrm{R}^{2}$ & 0.024 & 0.029 & 0.022 & -0.003 \\
\hline
\end{tabular}


related to Shupp et al. (2017) who find that risk aversion increased for people who were injured in the Oklahoma tornado in 2013, but it decreased for those who saw the injuries of others. None of the experienced firefighters in our sample had been seriously injured. On the other hand, they had often observed injuries of others.

The evidence presented in this paper might have some practical implications. It is possible that the experience makes people too risk-seeking from a normative point of view. Senior employees in charge of a team of co-workers might make choices that are careless because their attitudes to risk have changed by a long-term exposure to traumatic experiences. Also, these workers might engage in risky or dangerous behavior outside of work. Possible adverse outcomes might be prevented if special psychological care is offered for some of the highest-risk professions.

\section{Acknowledgments}

We would like to thank Michal Křizz of the Fire Rescue Service of the Czech Republic for helping us with the organization of the experiment with firefighters, and Michaela Bódiová, Katarína Čellárová, Monika Líbalová and Hedvika Navrátilová for excellent research assistance.

\section{Funding}

This work was supported by the Czech Science Foundation [grant number GA18-19492S].

\section{References}

Ahn, T. (2010). Attitudes toward risk and self-employment of young workers. Labour Economics, 17(2):434-442.

Ampudia, M. and Ehrmann, M. (2017). Macroeconomic experiences and risk taking of euro area households. European Economic Review, 91:146-156.

Barsky, R. B., Juster, F. T., Kimball, M. S., and Shapiro, M. D. (1997). Preference parameters and behavioural heterogeneity: An experimental approach in the health and retirement study. The Quarterly Journal of Economics, 112(2):537-579.

Bchir, M. A. and Willinger, M. (2013). Does the exposure to natural hazards affect risk and time preferences? some insights from a field experiment in peru. LAMETA Working Papers 13-04.

Bock, O., Nicklisch, A., and Baetge, I. (2012). Hamburg registration and organization online tool. H-Lab Working Paper, (1).

Bonin, H., Dohmen, T., Falk, A., Huffman, D., and Sunde, U. (2007). Cross-sectional earnings risk and occupational sorting: The role of risk attitudes. Labour Economics, 14(6):926-937.

Brown, S., Dietrich, M., Ortiz-Nunez, A., and Taylor, K. (2011). Self-employment and attitudes towards risk: Timing and unobserved heterogeneity. Journal of Economic Psychology, 32(3):425-433. 
Brown, S., Farrell, L., Harris, M. N., and Sessions, J. G. (2006). Risk preference and employment contract type. Journal of the Royal Statistical Society Series A, 169(4):849-863.

Bucciol, A. and Zarri, L. (2013). Financial risk aversion and personal life history. Working Papers, 05.

Cameron, L. and Shah, M. (2015). Risk-taking behavior in the wake of natural disasters. Journal of Human Resources, 50(2):484-515.

Cassar, A., Healy, A., and von Kessler, C. (2017). Trust, risk, and time preferences after a natural disaster: Experimental evidence from thailand. World Development, 94:90-105.

Cramer, J. S., Hartog, J., Jonker, N., and Van Praag, M. (2002). Low risk aversion encourages the choice for entrepreneurship: an empirical test of a truism. Journal of Economic Behavior E Organization, 48:29-36.

Crosetto, P. and Filippin, A. (2013). The bomb risk elicitation task. Journal of Risk and Uncertainty, 47(1):31-65.

190 Di Mauro, C. and Musumeci, R. (2011). Linking risk aversion and type of employment. Journal of Socio-Economics, 40(5):490-495.

Dohmen, T., Falk, A., Huffman, D., Sunde, U., Schupp, J., and Wagner, G. G. (2011). Individual risk attitudes: Measurement, determinants, and behavioral consequences. Journal of the European Economic Association, $9(3): 522-550$.

Eckel, C. C., El-Gamal, M. A., and Wilson, R. K. (2009). Risk loving after the storm: A bayesian-network study of hurricane katrina evacuees. Journal of Economic Behavior \& Organization, 69:110-124.

Guiso, L. and Paiella, M. (2008). Risk aversion, wealth, and background risk. Journal of the European Economic Association, 6(6):1109-1150.

Gurdal, M. Y., Kuzuba, T. U., and Saltoglu, B. (2017). Measures of individual risk attitudes and portfolio choice: Evidence from pension participants. Journal of Economic Psychology, 62(C):186-203.

Hanaoka, C., Shigeoka, H., and Watanabe, Y. (2016). Do risk preferences change? evidence from panel data before and after the great east japan earthquake. NBER Working Paper No. w21400.

Hartog, J., Ferrer-i Carbonell, A., and Jonker, N. (2002). Linking measured risk aversion to individual characteristics. Kyklos, 55(1):3-26.

205 Hvide, H. K. and Panos, G. A. (2014). Risk tolerance and entrepreneurship. Journal of Financial Economics, 111(1):200-223.

Kim, Y.-I. and Lee, J. (2014). The long-run impact of a traumatic experience on risk aversion. Journal of Economic Behavior \& Organization, 108:174-186. 
Malmendier, U. and Nagel, S. (2011). Depression babies: Do macroeconomic experiences affect risk taking? The Quarterly Journal of Economics, 126(1):373-416.

Malmendier, U., Tate, G., and Yan, J. (2011). Overconfidence and early life experiences: The effect of managerial traits on corporate financial policies. Journal of Finance, 66(5):1687-1733.

Masclet, D., Colombier, N., Denant-Boemont, L., and Loheac, Y. (2009). Group and individual risk preferences: A lottery-choice experiment with self-employed and salaried workers. Journal of Economic Behavior E Organization, $70(3): 470-484$.

Palsson, A.-M. (1996). Does the degree of relative risk aversion vary with household characteristics? Journal of Economic Psychology, 17(6):771-787.

Shupp, R., Loveridge, S., Skidmore, M., Lim, J., and Rogers, C. (2017). Risk, loss, and ambiguity aversion after a natural disaster. Economics of Disasters and Climate Change, 1(2):121-142.

Skriabikova, O. J., Dohmen, T., and Kriechel, B. (2014). New evidence on the relationship between risk attitudes and self-employment. Labour Economics, 30:176-184.

Tanaka, T., Camerer, C. F., and Nguyen, Q. (2010). Risk and time preferences: linking experimental and household survey data from vietnam. The American Economic Review, 100(1):557-571.

Voors, M. J., Nillesen, E. E. M., Verwimp, P., Bulte, E. H., Lensink, R., and Van Soest, D. P. (2012). Violent conflict and behavior: A field experiment in burundi. The American Economic Review, 102(2):941-964. 


\section{MUNI Econ Working Paper Series (since 2018)}

2019-05 Krčál, O., Staněk, R., Slanicay, M. (2019). Made for the job or by the job? A lab-in-the-field experiment with firefighters. MUNI ECON Working Paper n. 2019-05. Brno: Masaryk University. https://doi.org/10.5817/WP_MUNI_ECON_2019-05

2019-04 Bruni, L., Pelligra, V., Reggiani, T., Rizzolli, M. 2019. The Pied Piper: Prizes, Incentives, and Motivation Crowding-in. MUNI ECON Working Paper n. 2019-04. Brno: Masaryk University. https://doi.org/10.5817/WP_MUNI_ECON_2019-04

2019-03 Krčál, O., Staněk, R., Karlínová, B., Peer, S. 2019. Real consequences matters: why hypothetical biases in the valuation of time persist even in controlled lab experiments. MUNI ECON Working Paper n. 2019-03. Brno: Masaryk University. https://doi.org/10.5817/WP_MUNI_ECON_2019-03

2019-02 Corazzini, L., Cotton, C., Reggiani, T., 2019. Delegation And Coordination With Multiple Threshold Public Goods: Experimental Evidence. MUNI ECON Working Paper n. 2019-02. Brno: Masaryk University. https://doi.org/10.5817/WP_MUNI_ECON_2019-02

2019-01 Fišar, M., Krčál, O., Staněk, R., Špalek, J. 2019. The Effects of Staff-rotation in Public Administration on the Decision to Bribe or be Bribed. MUNI ECON Working Paper n. 2019-01. Brno: Masaryk University. https://doi.org/10.5817/WP_MUNI_ECON_2019-01

2018-02 Guzi, M., Kahanec, M. 2018. Income Inequality and the Size of Government: A Causal Analysis. MUNI ECON Working Paper n. 2018-02. Brno: Masaryk University. https://doi.org/10.5817/WP_MUNI_ECON_2018-02

2018-01 Geraci, A., Nardotto, M., Reggiani, T., Sabatini, F. 2018. Broadband Internet and Social Capital. MUNI ECON Working Paper n. 2018-01. Brno: Masaryk University. https://doi.org/10.5817/WP_MUNI_ECON_2018-01

ISSN electronic edition 2571-130X

MUNI ECON Working Paper Series is indexed in RePEc:

https://ideas.repec.org/s/mub/wpaper.html 